REPRESENTING THE ENGLISH RENAISSANCE STEPHEN GREENBLATT, Editor Greenblatt provides a brilliant sampling of the innovative new methods currently transforming the interpretation of culture. A Representations Book \$37.50 cloth, \$12.95 paper

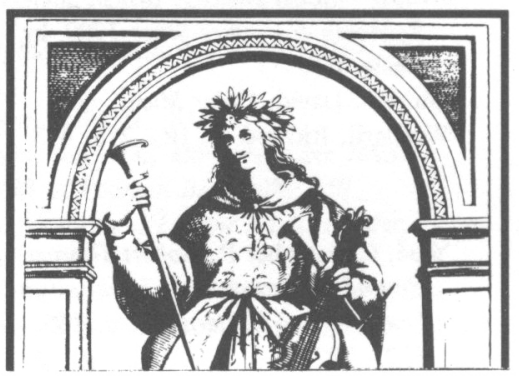

\section{POLITICS OF DISCOURSE}

The Literature and History of 17th-Century England

\section{KEVIN SHARPE and}

STEVEN N. ZWICKER, Editors

These outstanding essays explore the interdependency of literature and history in 17th-century England and examine the relation of text to society.

\$49.95 cloth, \$14.95 paper

At bookstores or call toll-free 800822-6657. Visa \& MasterCard only.

University of California Press Berkeley 94720

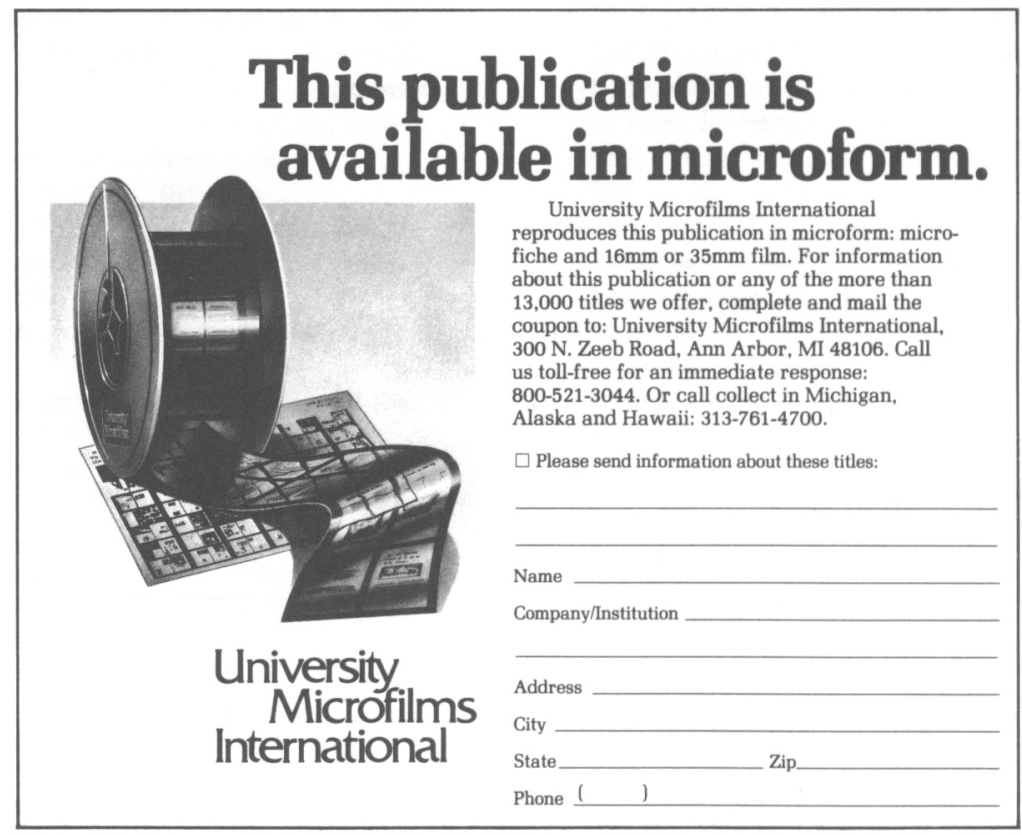




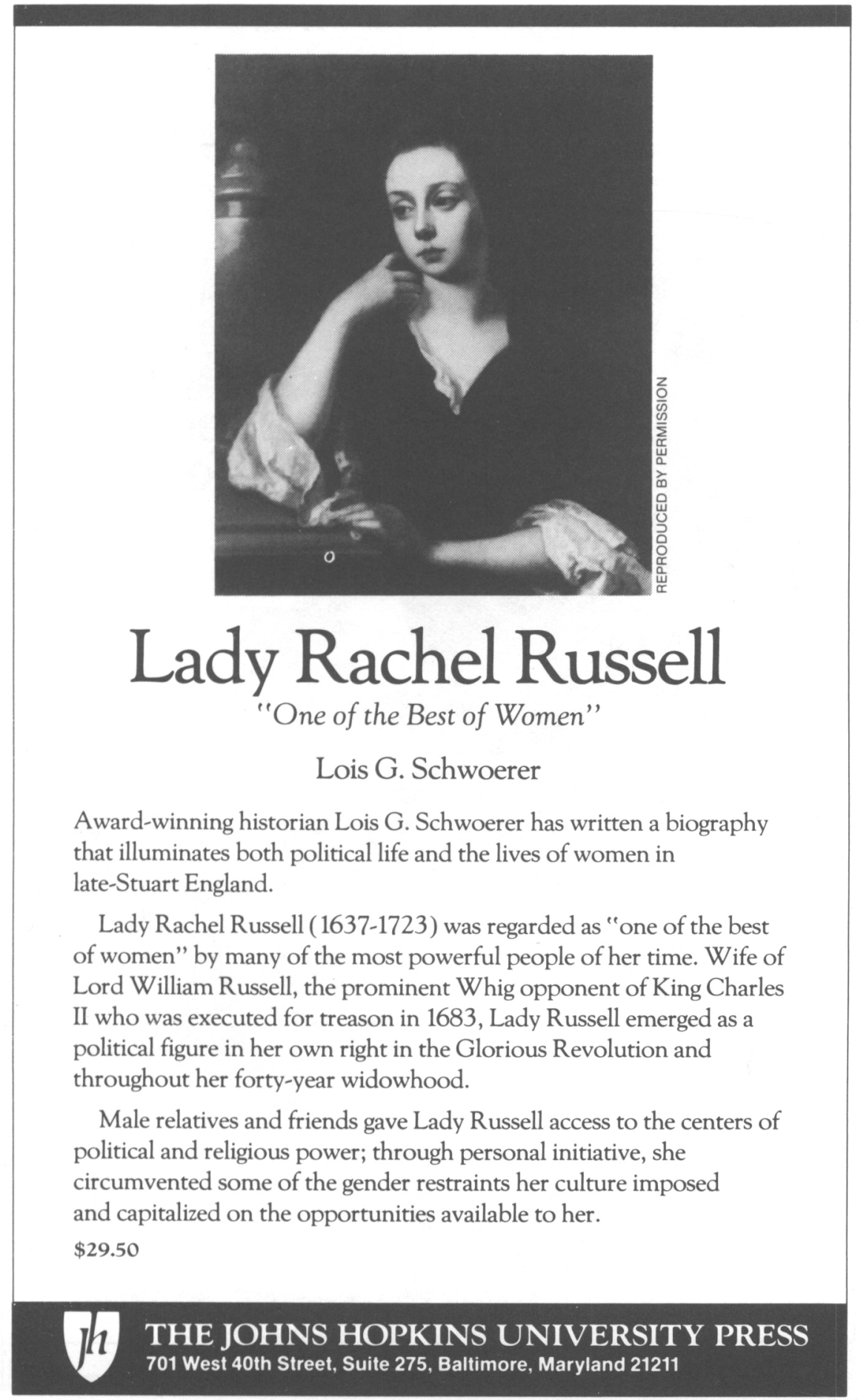




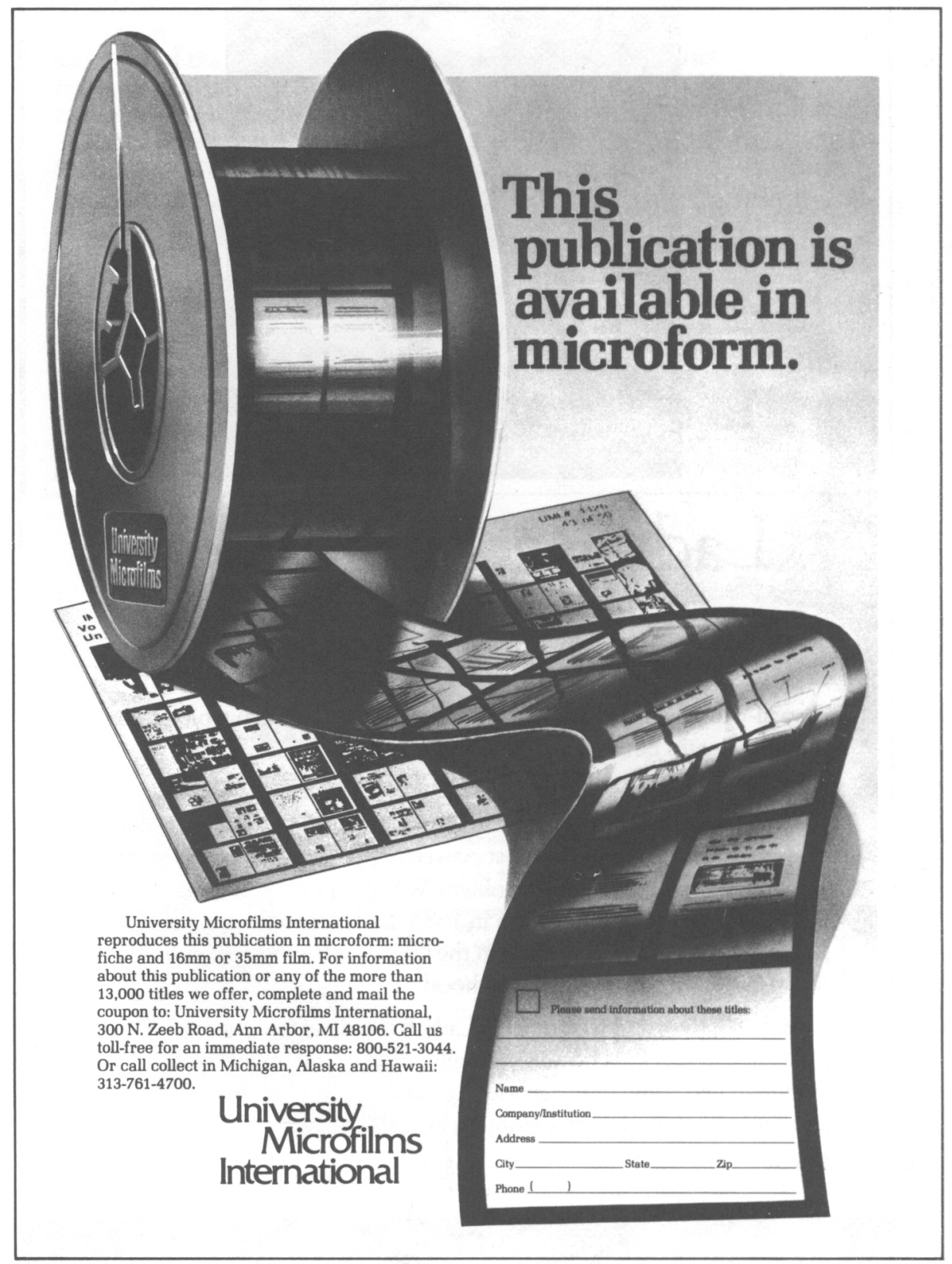




\section{Oxford}

\section{Bound for America}

The Transportation of British Convicts to the Colonies, 1718-1775

A ROGER EKIRCH, Virginia Polytechnic Institute and State Untversity

Assessing the impact of the 50,000 British convicts who were banished to colonial America between 1718 and 1785, Ekırch reveals the critical role banıshment played in Britain's crimınal justice system

$1987288 \mathrm{pp}$, illus , \$39 95

\section{The Historicity of Romantic Discourse}

\section{CLIFFORD H SISKIN, Wayne State Untverstty}

"Siskin's work is original and provocative-even as it makes us rethınk such terms It should spark the kind of vigorous debates among Romanticists and cultural critics that the profession sorely needs"-Mary Poovey, The Johns Hopkins University

$1987 \quad 240 \mathrm{pp} \quad \$ 2250$

\section{British Writers of the Thirties}

VALENTINE CUNNINGHAM, Corpus Christ College, Oxford

A kaleidoscopic, wide-ranging study of British writers of the 1930s, this book highlights the 1roposing images of the era and places the writers firmly within their social, political, historical, and ideological context

February $1988544 \mathrm{pp} \quad \$ 5500$

\section{John Fielden and the Politics of Popular Radicalism}

\section{2-1847}

STEWART ANGAS WEAVER, Untversity of Rochester

Known best as a leader of factory reform, John Fielden was also an industrial magnate and radical Member of Parliament This biography provides a fresh assessment of the movements in which he was involved and offers a new perspective on England's turbulent years between 1832 and 1847

$1987332 \mathrm{pp} \$ 6200$

\section{Lives of the Lord Chancellors}

R F V HEUSTON, University of Cambridge

"Beautifully written throughout, and constructed with a great sense of balance and proportion In addition Mr Heuston's scholarship appears to be impeccable, on both the political and the legal side"-Observer

Illuminating some of the most remarkable figures and events in English legal and political life, this set of biographies describes the prestigious leaders who have served as Lord Chancellor

Volume I 1885-1940

$1987656 \mathrm{Pp}$, plates $\$ 9600$

Volume II 1940-1970

$1987268 \mathrm{pp}$, plates $\$ 5400$

Prices and publication dates are subject to change

To order, send check or money order to

Humantites and Social Sciences Marketing Department

\section{Oxford University Press}

200 Madison Avenue • New York, NY 10016 


\section{WILLIAM LORD HERBERT OF PEMBROKE (C. 1507-1570)}

This work is a political biography of a Tudor

courtier-councillor, William Herbert, which

reveals a different portrait of the

man than earlier antiquarian

accounts. The author posits

that Sir William was a politique

and a successful politician who was

mindful as much of his personal

interests as those of his country. This is an

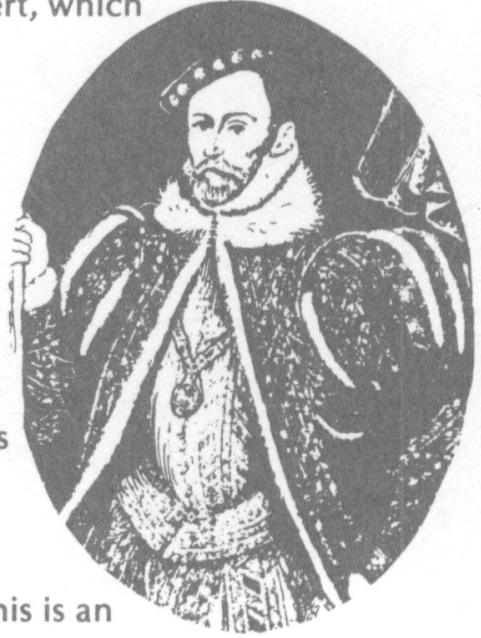

entirely new verdict on this Tudor statesman.

ISBN 0-88946-458-8 Volume 6

(SBH) Studies in British History

List Price \$39.95

\section{SPECIAL PREPUBLICATION PRICE \\ $\$ 19.95$ \\ with mention of this ad.}

We invite proposals for monographs, bibliographies, and other texts for inclusion in our monograph series STUDIES IN BRITISH

HISTORY.Please request our catalog which contains a listing of all our books in British History and describes our publishing program and includes a manuscript proposal form. 